\title{
Concentrations, profiles, and emission factors of unintentionally produced persistent organic pollutants in fly ash from coking processes
}

\author{
Guorui Liu ${ }^{\mathrm{a}, \mathrm{b}}$, Wenbin Liu ${ }^{\mathrm{a}}$, Zongwei Cai ${ }^{\mathrm{b}}$, Minghui Zheng ${ }^{\mathrm{a}, *}$ \\ a State Key Laboratory of Environmental Chemistry and Ecotoxicology, Research Center for Eco-Environmental Sciences, Chinese Academy of Sciences, P.O. \\ Box 2871, Beijing 100085, China \\ ${ }^{\mathrm{b}}$ Department of Chemistry, Hong Kong Baptist University, Kowloon Tong, Kowloon, Hong Kong Special Administrative Region
}

\section{H I G H L I G H T S}

- Fly ash was identified as a route of POPs release from the coking industry.

- Emission factors were derived for unintentionally produced POPs in coking ash.

- The data obtained were useful for developing an integrated source inventory.

- Congener profiles for the unintentionally produced POPs in coking ash are presented.

\section{A R T I C L E I N F O}

\section{Article history:}

Received 20 April 2013

Received in revised form 12 July 2013

Accepted 29 July 2013

Available online 4 August 2013

\section{Keywords:}

Dioxins

Polychlorinated biphenyls

Polychlorinated naphthalenes

Coking process

Fly ash

\section{G R A P H I C A L A B S T R A C T}

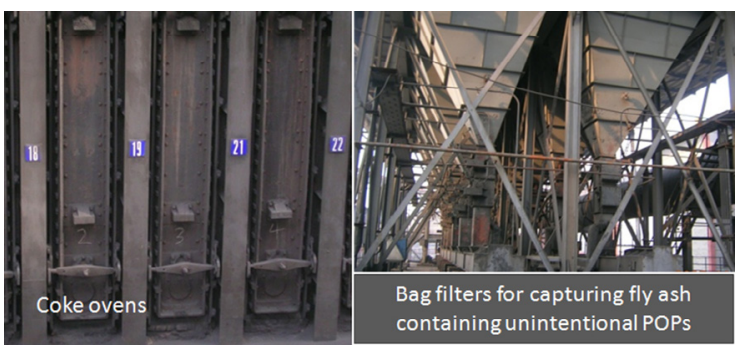

\begin{abstract}
A B S T R A C T
The coking process has been found to be an important source of unintentionally produced persistent organic pollutants (UP-POPs). However, the concentrations, profiles, and emission factors of UP-POPs in fly ash from coke plants have not been studied. In this study, six UP-POPs (polychlorinated dibenzo-p-dioxins (PCDDs), polychlorinated dibenzofurans (PCDFs), polychlorinated biphenyls (PCBs), polychlorinated naphthalenes (PCNs), hexachlorobenzene ( $\mathrm{HxCBz}$ ), and pentachlorobenzene $(\mathrm{PeCBz})$ ) were identified and quantified in fly ash from eight coke plants. The average concentrations of the PCDDs, PCDFs, and "dioxin-like" PCBs were 1.5, 2.26, and 0.26 pg TEQg $^{-1}$, respectively, and the average concentrations of the PCNs, $\mathrm{HxCBz}$, and PeCBz were 256, 290, and $146 \mathrm{pg} \mathrm{g}^{-1}$, respectively. The proportion each homolog contributed to the total concentration of the PCDFs, PCBs, and PCNs decreased with increasing chlorination level. The PCDFs contributed the biggest proportion of the total UP-POPs toxic equivalents (TEQs), and the average emission factors in fly ash were $10.5,17.3$, and $1.82 \mathrm{ng} \mathrm{TEQ}^{-1}$ for the PCDDs, PCDFs, and "dioxin-like" PCBs, respectively, and 1792, 2028, and $1025 \mathrm{ng} \mathrm{t}^{-1}$ for the PCNs, HxCBz, and $\mathrm{PeCBz}$, respectively. These data are essential for establishing an integrated UP-POP release inventory.
\end{abstract}

(C) 2013 Elsevier B.V. All rights reserved.

\section{Introduction}

Since the discovery of polychlorinated dibenzo-p-dioxins (PCDDs) and polychlorinated dibenzofurans (PCDFs) in flue gases and fly ash from municipal solid waste incinerators in 1977 [1],

\footnotetext{
* Corresponding author. Tel.: +8610 6284 9172; fax: +861062923563.

E-mail address: zhengmh@rcees.ac.cn (M. Zheng).
}

the formation and emission of PCDDs and PCDFs (PCDD/Fs) and other "dioxin-like" (dl-) compounds has attracted increasing concern because of their adverse effects on the environment and human health [2-6]. Other dl-compounds, such as polychlorinated biphenyls (PCBs), polychlorinated naphthalenes (PCNs), hexachlorobenzene $(\mathrm{HxCBz})$, and pentachlorobenzene (PeCBz), can also be unintentionally produced and released during thermal processes [7,8], and these chemicals (including the PCDD/Fs) are called unintentionally produced persistent organic pollutants 
Table 1

Basic information on the coke plants studied.

\begin{tabular}{|c|c|c|c|c|c|c|c|c|}
\hline Site name & P1 & P2 & P3 & P4 & P5 & P6 & P7 & P8 \\
\hline Height of ovens (m) & 6 & 6 & 7.3 & 4.3 & 4.3 & 6 & 4.3 & 4.3 \\
\hline Annual capacity (million ton) & 0.5 & 1.8 & 2.2 & 0.6 & 1 & 1 & 0.96 & 0.7 \\
\hline Coal charging technique & $\mathrm{TC}^{\mathrm{a}}$ & $\mathrm{TC}$ & $\mathrm{TC}$ & TC & $\mathrm{SC}^{\mathrm{b}}$ & $\mathrm{TC}$ & SC & TC \\
\hline Coke quenching method & Water & Nitrogen & Nitrogen & Water & Water & Water & Water & Water \\
\hline $\mathrm{APCD}^{\mathrm{c}}$ & $\mathrm{BFs}^{\mathrm{d}}$ & BFs & BFs & BFs & BFs & $\mathrm{BFs}$ & BFs & BFs \\
\hline Origin of fly ash & $\mathrm{PC}^{\mathrm{e}} ; \mathrm{CC}$ & $\mathrm{PC}^{\mathrm{f}} ; \mathrm{CC} ; \mathrm{QC}^{\mathrm{g}}$ & PC; & PC & PC; CC & PC; CC & PC & CC; PC \\
\hline $\begin{array}{l}\text { Amount of fly ash produced for per ton } \\
\text { of coke production }\left(\mathrm{kg} \mathrm{t}^{-1}\right)\end{array}$ & 7 & 6 & 5 & 9 & 9 & 6 & 10 & 7 \\
\hline
\end{tabular}

\footnotetext{
a Top charging.

b Stamp charging.

c Air pollution control device.

d Bag filters.

e The ash was collected during the pushing of the coke.

$\mathrm{f}$ The ash was collected during the charging of the coal.

$\mathrm{g}$ The ash was collected during the quenching of the coke.
}

(UP-POPs) [9]. Identifying and quantifying UP-POPs in various anthropogenic sources is the primary step in controlling their emission and reducing the environmental burden of, and human exposure to, these compounds $[10,11]$.

Stack gas and residue emissions are the two main ways UP-POPs are released from industries that have major thermal processes. Heterogeneous reactions during thermal processes are the dominant UP-POP formation mechanisms [12], and fly ash is considered to be an important matrix for catalyzing these heterogeneous reactions because it contains relatively large amounts of carbon and catalytic elements [13-16]. High UP-POPs concentrations have been found in fly ash samples from various thermal industries, so fly ash is considered to be one of the most important sources of UP-POPs to the environment [17].

It has been speculated that the coking process is a potential source of UP-POPs, because it has conditions that are essential for UP-POP formation, including macromolecular materials in coal (the carbon source), chlorine (inorganic or organic), catalytic metal elements in the raw materials, and suitable temperature ranges. We have confirmed that the coking process is a potential source of UP-POPs by characterizing stack gas emissions from coking plants in previous studies $[9,10]$. However, concentrations, profiles, and emission factors of UP-POPs in fly ash from coking plants have not been reported up to now, and these are essential for developing an integrated UP-POP release inventory for the coking industry.

In this study, we collected fly ash samples from eight coke plants in China, and determined six types of UP-POPs in the samples using isotope dilution gas chromatography-mass spectrometry. The primary aims of the study were: (1) to quantify the concentrations of UP-POPs in fly ash samples from coking processes, to understand the release of UP-POPs in coking ash; (2) to assess the UP-POP profiles in fly ash, which could help understand the UP-POP formation mechanisms and identify specific sources; and (3) to derive emission factors for UP-POPs in fly ash, so that an integrated UP-POP release inventory for the coking industry can be developed. To the best of our knowledge, this is the first intensive investigation of the concentrations, profiles, and emission factors of UP-POPs in fly ash from the coking industry. Because of the scale of industrial activity in China, the UP-POP emission data for typical Chinese coke plants produced from this study might have significant implications for evaluating UP-POP emissions from the global coking industry.

\section{Experimental}

\subsection{Sampling and information on the coke plants studied}

Coke is produced by carbonizing coal in an oven that is externally heated to approximately $1000^{\circ} \mathrm{C}$ in the absence of air. The coke is removed from the oven and quenched with water or dry inert gas. The formation and emission of UP-POPs can occur during three different stages of the process, including charging the coal (CC), pushing the coke (PC), and quenching the coke (QC). The coke production process has been described in detail previously [9], and a schematic of the coking process is presented in the Supplementary Material (Fig. S1). In this study, UP-POPs were analyzed in fly ash emitted from eight coke plants that were of different sizes and that used different operational techniques. The height of the coke ovens in the plants ranged from 4.3 to $7.3 \mathrm{~m}$, and the coke plants used either top charging or stamp charging of coal, and either water quenching or inert gas quenching of the coke. Samples of the fly ash produced during the CC, PC, and QC processes were collected separately, from the fabric bag filters used to clean the emissions. The origins (CC, PC, or QC) of the fly ash collected are given in Table 1 . The fly ash samples were collected using a stainless steel spoon. Each composite fly ash sample comprised 3-6 subsamples from the chosen sampling points. The fly ash samples were tightly wrapped in aluminum foil and sealed in polyethylene (PE) bags to avoid contamination and loss. The samples were stored in a refrigerator until analysis. Detailed information on the coke plants studied and on the fly ash samples collected is given in Table 1.

\subsection{Chemical analysis}

PCDDs, PCDFs, and PCBs were analyzed by isotope dilution high resolution gas chromatography-high resolution mass spectrometry (HRGC/HRMS), using modified US Environmental Protection Agency (EPA) methods 8290 (PCDD/Fs) and 1668A (PCBs). The detailed sample extraction, cleanup, and instrumental analysis procedures for the PCDD/Fs and dl-PCBs have been described in detail by Ba et al. [17]. Briefly, the fly ash samples were spiked with known amounts of ${ }^{13} \mathrm{C}_{12}$-labeled PCDD, PCDF, and PCB internal standards, treated with $1 \mathrm{~mol} \mathrm{~L}^{-1} \mathrm{HCl}$, then Soxhlet extracted with $250 \mathrm{~mL}$ of toluene for about $24 \mathrm{~h}$. The extracts were concentrated in a rotary evaporator, then subjected to a series of cleanup steps, including columns containing silica gel treated with $44 \%$ (by weight) sulfuric acid and multilayer silica gel columns. PCDDs, PCDFs, and PCBs were then fractionated using basic alumina columns, each of the fractions was reduced to about $20 \mu \mathrm{L}$ by rotary evaporation and under a gentle stream of nitrogen, and ${ }^{13} \mathrm{C}_{12}$-labeled PCDD, PCDF, and PCB injection standards were added.

PCNs were analyzed using an isotope dilution HRGC/HRMS method that has been described previously $[10,18]$. Briefly, the samples were spiked with known amounts of ${ }^{13} \mathrm{C}_{10}$-labeled PCN internal standards (catalog no. ECN-5102, containing ${ }^{13} \mathrm{C}_{10}$-PCNs27, -42, -52, -67, -73, and -75; Cambridge Isotope Laboratories, Andover, MA, USA). The samples were Soxhlet extracted and the 

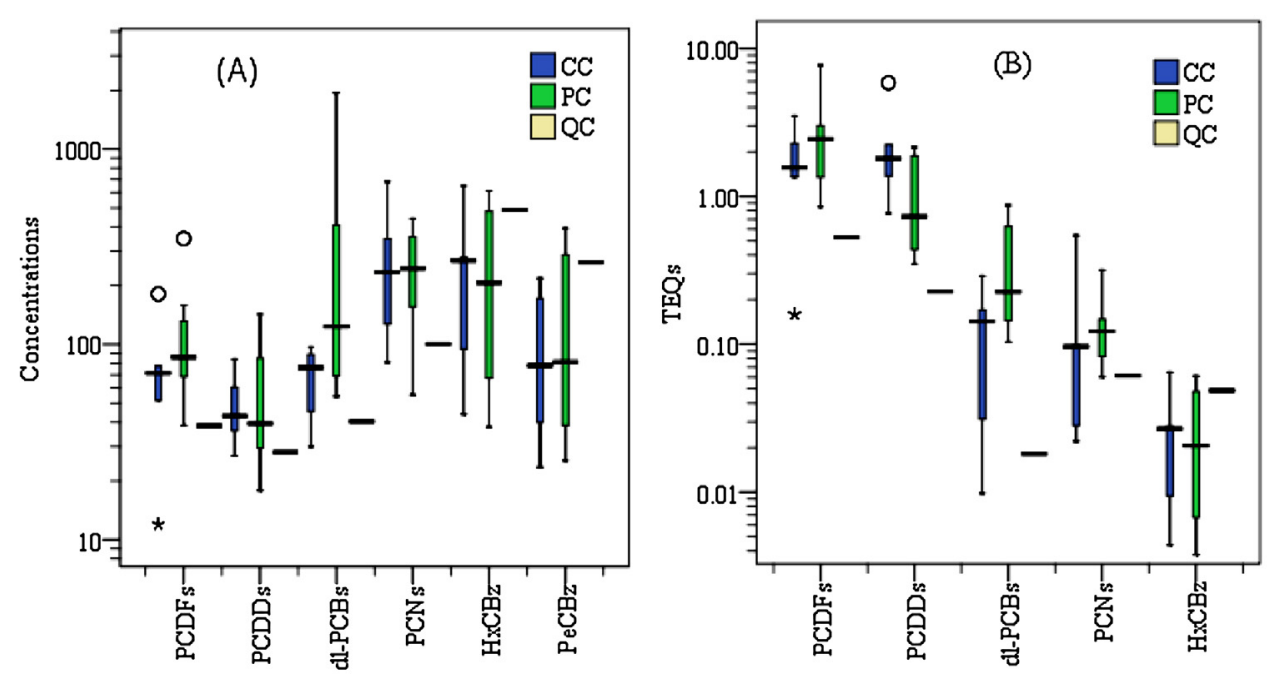

Fig. 1. Concentrations (A, $\left.\mathrm{pg} \mathrm{g}^{-1}\right)$ and TEQs (B, pg TEQ $\left.\mathrm{g}^{-1}\right)$ of the UP-POPs investigated.

cleanup was the same as for the PCBs. The final extracts were reduced to about $20 \mu \mathrm{L}$ and a ${ }^{13} \mathrm{C}_{10}$-labeled $\mathrm{PCN}-64$ injection standard (catalog no. ECN-5260; Cambridge Isotope Laboratories) was added.

The PCDD, PCDF, PCB, and PCN congeners were identified and quantified using an HRGC/HRMS instrument, monitoring two ions for each analyte. Separation was achieved using a DB-5ms fused silica column ( $60 \mathrm{~m}$ long, $0.25 \mathrm{~mm}$ i.d., $0.25 \mu \mathrm{m}$ film thickness; J\&W, Agilent Technologies Inc., Santa Clara, CA, USA). The HRMS instrument was operated at around 10,000 resolution, in selected ion monitoring mode.

For the analysis of $\mathrm{HxCBz}$ and $\mathrm{PeCBz}$, the samples were spiked with known amounts of ${ }^{13} \mathrm{C}_{6}$-labeled polychlorinated benzenes (PCBzs) (catalog no. EM-1725-A; Cambridge Isotope Laboratories), including ${ }^{13} \mathrm{C}_{6}-\mathrm{HxCBz}$ and ${ }^{13} \mathrm{C}_{6}-\mathrm{PeCBz}$, extracted, and then purified using multilayer silica gel columns. The extracts were then analyzed for $\mathrm{HxCBz}$ and PeCBz using an Agilent 6890 GC (Agilent Technologies Inc.) equipped with a DB-5ms capillary column $(30 \mathrm{~m}$ long, $0.25 \mathrm{~mm}$ i.d., $0.25 \mu \mathrm{m}$ film thickness; J\&W) interfaced with an Agilent $5973 \mathrm{~N}$ MSD. $\mathrm{HxCBz}$ and $\mathrm{PeCBz}$ were quantified using ${ }^{13} \mathrm{C}_{6}-\mathrm{HxCBz}$ and ${ }^{13} \mathrm{C}_{6}-\mathrm{PeCBz}$ as isotope dilution internal standards.

\subsection{Quality assurance and quality control}

To identify a particular analyte, its retention time had to be within $2 \mathrm{~s}$ of the retention time of the equivalent internal standard and the ratio between the monitored ions for the analyte had to be within $15 \%$ of the theoretical value. The recoveries were $39-82 \%$ for the ${ }^{13} C_{12}$-labeled PCDD/Fs and $42-138 \%$ for the ${ }^{13} \mathrm{C}_{12}$-labeled PCBs, which met the requirements of US EPA methods 8290 and $1668 \mathrm{~A}$. The recoveries of the ${ }^{13} \mathrm{C}_{10}$-labeled PCNs were $36-125 \%$ and the recoveries of ${ }^{13} \mathrm{C}_{6}-\mathrm{HxCBz}$ and ${ }^{13} \mathrm{C}_{6}-\mathrm{PeCBz}$ were $34-72 \%$. Laboratory method blank samples were included with each sample batch analyzed, and octachlorodibenzo-p-dioxin (OCDD), octachlorodibenzofuran (OCDF), PCB-28, PCN-1, and PCN2 were found in the blanks at concentrations above their LODs but at much lower than $10 \%$ of the concentrations found in samples. The analytical laboratory had participated in a number of international PCDD, PCDF, and PCB intercalibration studies, using fly ash from waste incinerators, organized by the UNEP, Intercal AB (Sweden), and the Norwegian Institute of Public Health. The laboratory generally performed at an acceptable level in these intercalibration studies, and, for example, the $z$-scores for the laboratory in the 13 th round of the international intercalibration study were within the range $-1<z$-scores $<+1$ for the PCDD, PCDF and dl-PCB toxic equivalents (TEQs) in fly ash samples from waste incinerators.

\section{Results and discussion}

\subsection{Concentrations of UP-POPs in fly ash samples}

The concentrations and TEQs of selected UP-POPs in the fly ash samples analyzed are presented in Fig. 1. WHO-TEF values published by van den Berg et al. [19] were used to calculate the PCDD, PCDF, and dl-PCB TEQs, and the PCN and HxCBz TEQs were calculated using the TEFs reported by Noma et al. [20] and van Birgelen et al. [21], respectively. The average concentrations found were $54.7 \mathrm{pg} \mathrm{g}^{-1}\left(1.50 \mathrm{pg} \mathrm{TEQ}^{-1}\right)$ for the PCDDs, $99.6 \mathrm{pg} \mathrm{g}^{-1}$ $\left(2.26 \mathrm{pg} \mathrm{TEQ}^{-1}\right)$ for the PCDFs, $266.3 \mathrm{pg} \mathrm{g}^{-1}\left(0.26 \mathrm{pg} \mathrm{TEQ}^{-1}\right)$ for the dl-PCBs, $256 \mathrm{pg} \mathrm{g}^{-1}\left(0.14 \mathrm{pg} \mathrm{TEQg}^{-1}\right)$ for the PCNs, $290 \mathrm{pg} \mathrm{g}^{-1}$ $\left(0.03 \mathrm{pg} \mathrm{TEQ}^{-1}\right)$ for $\mathrm{HxCBz}$, and $146 \mathrm{pg} \mathrm{g}^{-1}$ for PeCBz. However, fly ash from the QC process of only one plant was analyzed for UPPOPs, so the uncertainties involved in estimating UP-POP emission concentrations in QC fly ash for the whole coking industry from this sample are likely to be large. However, the QC process is not, at the moment, commonly used in the coking industry, so the effect this uncertainty will have on the emission estimates for the coking industry as a whole will not be very important.

It can be seen from Fig. 1 that the concentrations of the six types of UP-POPs that were analyzed in the fly ash samples decreased in the order PCBzs $>$ PCNs $>$ dl-PCBs $>$ PCDFs $>$ PCDDs, but that the TEQs decreased in the order PCDFs $>$ PCDDs $>$ dl-PCBs $>$ PCNs $>\mathrm{HxCBz}$. The concentration order PCBzs $>$ PCDFs $>$ PCDDs $>$ PCBs normally indicates de novo synthesis [22]. The PCDF to PCDD ratio $\left(R_{\mathrm{DF} / \mathrm{DD}}\right)$ has been used to identify the dominant formation mechanism(s) in a system, and many studies have shown that PCDD/Fs formed from precursors have $R_{\mathrm{DF} / \mathrm{DD}}$ values much lower than one, but that de novo synthesis normally gives $R_{\mathrm{DF} / \mathrm{DD}}$ values greater than one $[9,23]$. From Fig. 1, it can be seen that the PCDFs were present at much higher concentrations than the PCDDs, suggesting that they were predominantly formed by de novo synthesis during the coking processes.

To our knowledge, this study is the first time six UP-POPs have been intensively monitored in fly ash samples from coking plants, and no other data on UP-POPs in coking ash appear to be available for comparison. Waste incineration and metal smelting have been considered to be major sources of UP-POPs emissions from industries that use thermal processes. Thus, to assess which sources 


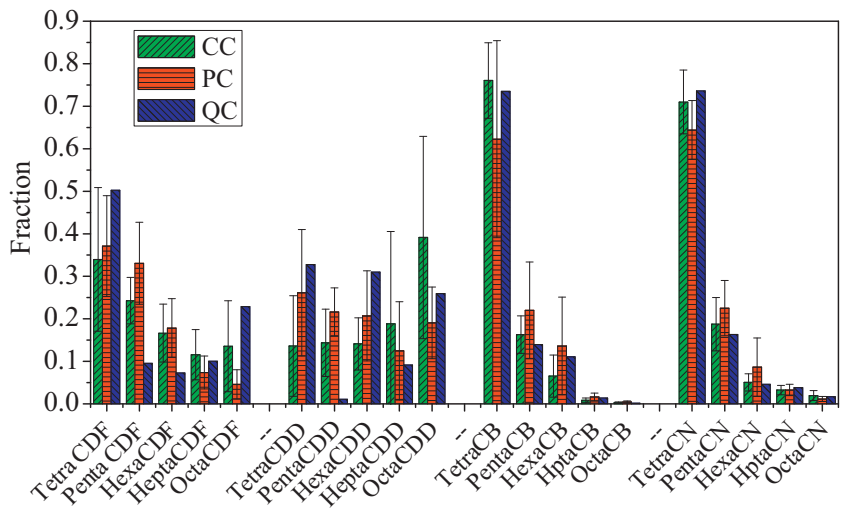

Fig. 2. $P C D D, P C D F, P C B$, and $P C N$ homolog profiles in the fly ash samples.

should be considered as priorities for decreasing the release of UPPOPs, the UP-POP concentrations we found in fly ash from coking processes were compared with the concentrations found in fly ash from waste incinerators and metallurgical plants (Fig. S2 in the Supplementary Material). The UP-POP concentrations were far lower in fly ash from the coking processes than from the waste incineration and metallurgical fly ash. The elemental compositions of the raw material and the fly ash are very important in the formation of UP-POPs $[13,24]$, and the effect of chlorine and sulfur on PCDD/F formation has been investigated in many studies $[25,26]$. The ratio of sulfur to chlorine $\left(R_{\mathrm{S} / \mathrm{Cl}}\right)$ normally correlates with the PCDD/F concentrations formed, with a low ratio indicating a high chlorine content, which can promote PCDD/F formation, and a low sulfur content, which inhibits PCDD/F formation. The municipal solid waste $R_{\mathrm{S} / \mathrm{Cl}}$ is about $1: 3$, and the $R_{\mathrm{S} / \mathrm{Cl}}$ for coal used for coking is about 5:1. Therefore, the high sulfur content of the coking coal could cause relatively little formation of UP-POPs, by inhibiting the Deacon reaction that is responsible for catalyzing the formation of molecular chlorine during de novo synthesis. The Deacon reaction and the inhibiting reaction are shown in Eqs. (3) and (4). Secondary copper and secondary aluminum smelting systems normally have much higher chlorine contents than other processes, because PVC and other organic materials are present in the wastes that are used as raw materials. Copper and aluminum are also able to catalyze the formation of UP-POPs, so more UP-POPs are normally formed during secondary metal smelting than in other thermal processes.

$\mathrm{CuCl}_{2}+1 / 2 \mathrm{O}_{2} \rightarrow \mathrm{CuO}+\mathrm{Cl}_{2}$

$\mathrm{CuO}+2 \mathrm{HCl} \rightarrow \mathrm{CuCl}_{2}+\mathrm{H}_{2} \mathrm{O}$

$2 \mathrm{HCl}+1 / 2 \mathrm{O}_{2} \rightarrow \mathrm{H}_{2} \mathrm{O}+\mathrm{Cl}_{2}$ (Deaconreaction) $[=$ Eqs.(1) $+(2)]$

$\mathrm{Cl}_{2}+\mathrm{SO}_{2}+\mathrm{H}_{2} \mathrm{O} \rightarrow \mathrm{SO}_{3}+2 \mathrm{HCl}($ inhibitingreaction $)$

\subsection{UP-POP profiles in fly ash samples}

The UP-POP homolog profiles in the fly ash samples are shown in Fig. 2. The proportion each PCDF, PCB, and PCN homolog contributed to the total concentration decreased with increasing number of chlorines. Chlorination has been shown to be one of the most important formation mechanisms for the PCDFs, PCBs, and PCNs during waste incineration [27]. Our homolog profiles suggested that chlorination might also be an important pathway for the formation of PCDFs, PCBs, and PCNs during the coking processes,

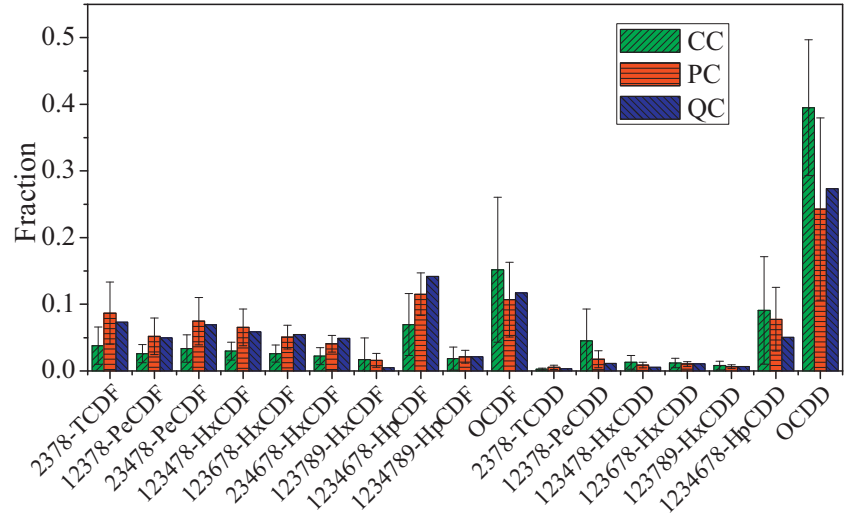

Fig. 3. PCDD/F congener profiles in the fly ash samples.

but different trends were observed for the PCDDs, indicating that the PCDD formation mechanism might be different from that of the PCDFs, PCBs, and PCNs. The homolog profiles for the three different processes (CC, PC, and QC) were very similar, indicating that similar formation mechanisms occurred in the different process for the UP-POPs investigated.

The congener profiles of the 17 2,3,7,8-substituted PCDD/Fs and the 12 dl-PCBs were used as signatures for the PCDD/Fs and dl-PCBs in the fly ash from the coking processes. To evaluate similarities and differences in the PCDD/F and dl-PCB patterns, the individual $\mathrm{PCDD} / \mathrm{F}$ and dl-PCB congener concentrations were normalized to the sum of the 2,3,7,8-substituted PCDD/F concentrations and the sum of the dl-PCB concentrations, respectively. The PCDD/F and dlPCB congener profiles are shown in Figs. 3 and 4, respectively. It can be seen that 1,2,3,4,6,7,8-heptachlorodibenzo-p-dioxin, OCDD, 1,2,3,4,6,7,8-heptachlorodibenzofuran, and OCDF were the dominant contributors to the sum of the 2,3,7,8-substituted PCDD/Fs. PCBs-118, -105 , and -77 were the top three dl-PCB congeners. The $\mathrm{PCDD} / \mathrm{F}$ and dl-PCB congener profiles were very similar in ash from each of the three coking processes (PC, CC, and QC). Strong similarities have also been seen in the PCDD/F and dl-PCB congener profiles of fly ash and stack gas emissions [9].

The concentration of each PCN congener was expressed as a fraction of the corresponding homolog concentration, to create the PCN congener profiles shown in Fig. 5. This normalization method minimizes the influence of the concentrations of different PCN homologs and allows the congener profiles to be compared more easily $[28,29]$. The $\mathrm{CN}-1$ fractions were slightly higher than the $\mathrm{CN}-2$ fractions for all three coking processes, and this is similar to what has been found for waste incinerators. However, the $\mathrm{CN}-1$

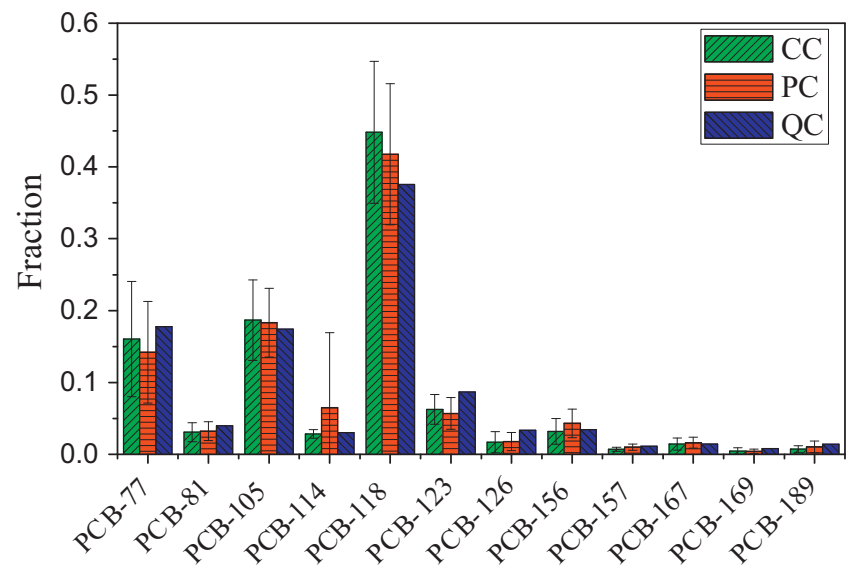

Fig. 4. dl-PCB congener profiles in the fly ash samples. 


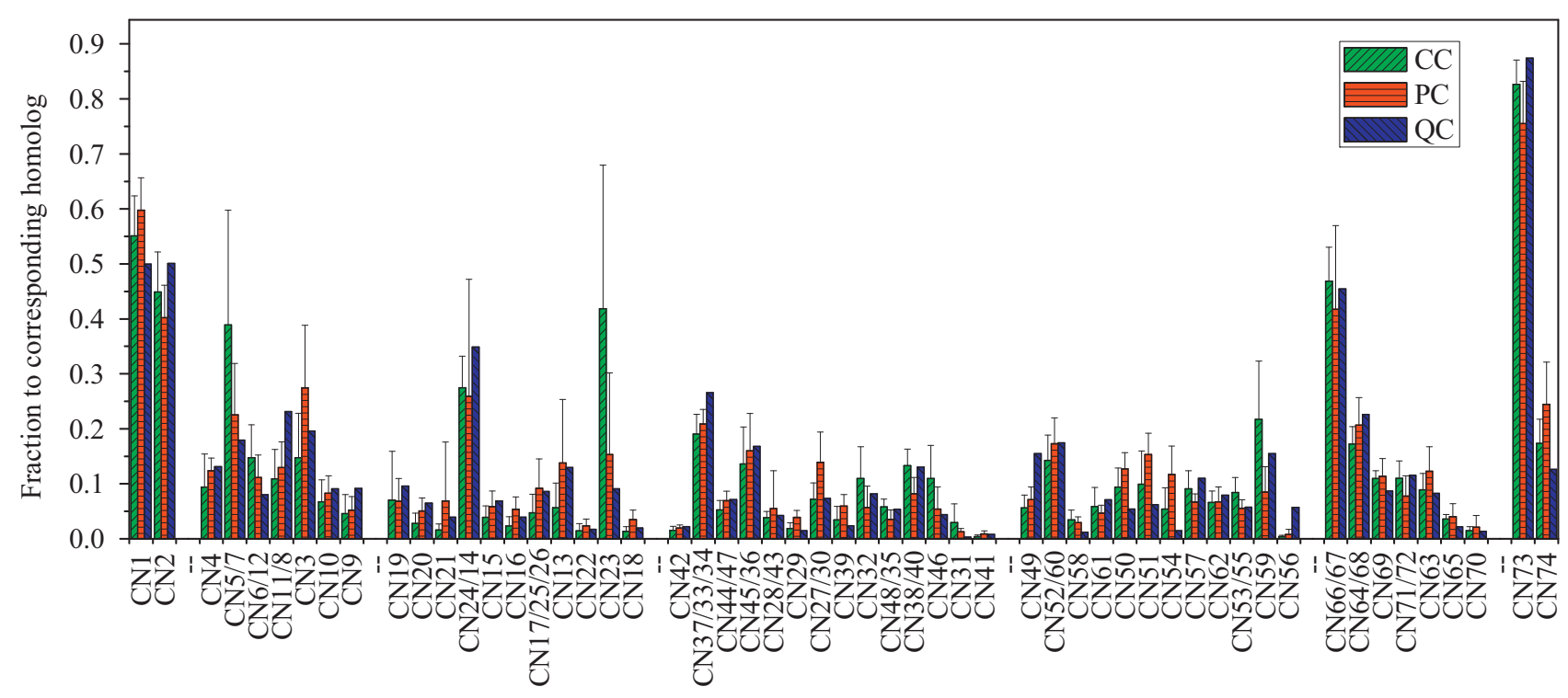

Fig. 5. PCN congener profiles (relative to the concentrations of the corresponding homologs) in the fly ash samples.

Table 2

Emission factors derived for the UP-POPs investigated in fly ash samples from coking processes.

\begin{tabular}{|c|c|c|c|c|c|c|c|c|c|c|c|c|c|}
\hline \multirow[t]{2}{*}{ UP-POPs } & \multirow[t]{2}{*}{ Num. of samples } & \multicolumn{6}{|c|}{ Mass emission factor $\left(\mathrm{ng} \mathrm{t}^{-1}\right)$} & \multicolumn{6}{|c|}{ TEQ emission factor (ng TEQ $\mathrm{t}^{-1}$ ) } \\
\hline & & Minimum & Maximum & Median & Mean & $\mathrm{SD}^{\mathrm{a}}$ & $\begin{array}{l}\text { Geometric } \\
\text { mean }\end{array}$ & Minimum & Maximum & Median & Mean & $\mathrm{SD}^{\mathrm{a}}$ & $\begin{array}{l}\text { Geometric } \\
\text { mean }\end{array}$ \\
\hline PCDFs & 14 & 84 & 2436 & 520 & 768 & 592 & 527 & 1.11 & 53.9 & 13.2 & 17.3 & 3.0 & 11.4 \\
\hline PCDDs & 14 & 125 & 997 & 276 & 383 & 274 & 316 & 1.59 & 41.0 & 8.52 & 10.5 & 1.6 & 7.21 \\
\hline dl-PCBs & 14 & 210 & 13,597 & 587 & 1864 & 3599 & 780 & 0.07 & 6.10 & 1.15 & 1.82 & 0.4 & 1.00 \\
\hline PCNs & 14 & 386 & 4774 & 1561 & 1792 & 1195 & 1443 & 0.15 & 3.80 & 0.68 & 0.97 & 0.2 & 0.69 \\
\hline $\mathrm{HxCBz}$ & 14 & 264 & 4536 & 1919 & 2028 & 1553 & 1352 & 0.03 & 0.45 & 0.19 & 0.20 & 0.04 & 0.14 \\
\hline $\mathrm{PeCBz}$ & 14 & 165 & 2754 & 628 & 1025 & 899 & 674 & - & - & - & - & - & - \\
\hline
\end{tabular}

a Standard deviation.

fraction was much higher than the $\mathrm{CN}-2$ fraction in technical PCN mixtures, including the Halowax mixtures [30]. The PCN congeners CNs-66/67 have been identified as indicators of combustion sources [31], and in this study we found that CNs-66/67 were dominant contributors to the hexa-CN homologs, suggesting that CNs-66/67 are also indicators of PCNs created in coking processes. The $\mathrm{CN}-73$ to $\mathrm{CN}-74$ ratio has been found to be important for differentiating PCN sources, and in this study this ratio was about 4:1 in the fly ash samples from the coking processes, in contrast to ratios much lower than ones that have been found for Halowaxes [20]. Generally speaking, the profiles indicated that the $\mathrm{PCN}$ congener profiles in fly ash from coking processes are, to some extent, similar to the profiles from waste incineration, but very different from the profiles in technical PCN mixtures. The congener profiles in the fly ash samples will provide more detailed fingerprints for use in PCN source apportionment studies.

\subsection{UP-POPs emission factors in fly ash from coking processes}

Emission factors are useful for estimating pollutant emissions from whole industries based on limited data. The release of ash residues is an important route of UP-POP release, in addition to stack gas emissions. Although we have published UP-POP emission factors to air from coking processes previously $[9,10]$, UP-POP emission factors in fly ash from coking processes, which are essential for developing a complete inventory, have not been available until now. We investigated the amounts of fly ash produced during the coking processes, so that emission factors for the UP-POPs in fly ash could be derived, and, on average, $7 \mathrm{~kg}$ of fly ash was produced per ton of coke produced (with a range of 5-10 kg per ton of coke produced). The UP-POP emission factors for fly ash were calculated using Eq. (5).

Emission factor $\left(\mathrm{ng} \mathrm{t}^{-1}\right)$

$=$ concentration $\left(\mathrm{pg} \mathrm{g}^{-1}\right)$

$\times$ amount of fly ash per ton of coke produced $\left(\mathrm{kg} \mathrm{t}^{-1}\right)$

The data ranges, averages, medians, and geometric means of the calculated UP-POP emission factors are shown in Table 2, and it can be seen that the average fly ash emission factors were 10.5 , 17.3 , and $1.82 \mathrm{ng} \mathrm{TEQ}^{-1}$ for the PCDDs, PCDFs, and dl-PCBs, respectively, and 1792, 2028, and $1025 \mathrm{ng} \mathrm{t}^{-1}$ for the PCNs, HxCBz, and $\mathrm{PeCBz}$, respectively. Emission factors for PCDDs, PCDFs, and other $\mathrm{dl}$-compounds in coke production residues are not available in the "Standardized toolkit for identification and quantification of dioxin and furan releases" prepared by UNEP [32], so the data from this study will be useful in updating this UNEP "toolkit". These data will also be useful for developing an integrated UP-POP release inventory for the coking industry.

\section{Conclusions}

We investigated eight typical coke plants of different sizes that used different techniques to estimate and characterize the emissions of UP-POPs in fly ash from the coking industry. The UP-POP concentrations in the fly ash samples collected from the coking plants were relatively low compared with concentrations reported in fly ash from waste incinerators and secondary nonferrous 
smelting plants. Of the UP-POPs investigated, PCDFs were the dominant contributors to the total TEQ values. The PCN congener profiles in the fly ash from the coking processes were similar, to an extent, to those from waste incineration and other thermal processes, but were clearly different from the congener profiles in technical PCN mixtures, and this information will improve the PCN fingerprint database for PCN source identification. We calculated UP-POP emission factors for fly ash, and these will be useful for developing an integrated UP-POP release inventory for the coking industry.

\section{Acknowledgments}

We gratefully acknowledge the support from the National 973 Program (No. 2009CB421606), the Hong Kong Scholars Program (XJ2012055), and the National Natural Science Foundation of China (Nos. 21107123 and 21037003).

\section{Appendix A. Supplementary data}

Supplementary data associated with this article can be found, in the online version, at http://dx.doi.org/10.1016/ j.jhazmat.2013.07.063.

\section{References}

[1] K. Olie, P.L. Vermeulen, O. Hutzinger, Chlorodibenzo-p-dioxins and chlorodibenzofurans are trace components of fly ash and flue gas of some municipal incinerators in the Netherlands, Chemosphere 6 (1977) 455-459.

[2] R. Weber, M. Tysklind, C. Gaus, Dioxin-contemporary and future challenges of historical legacies, Environmental Science and Pollution Research 15 (2008) 96-100.

[3] R. Weber, H. Hagenmaier, PCDD/PCDF formation in fluidized bed incineration, Chemosphere 38 (1999) 2643-2654.

[4] J.B. Wang, C.H. Hung, C.H. Hung, G.P. Chang-Chien, Polychlorinated dibenzop-dioxin and dibenzofuran emissions from an industrial park clustered with metallurgical industries, Journal of Hazardous Materials 161 (2009) 800-807.

[5] Z.Q. Nie, M.H. Zheng, G.R. Liu, W.B. Liu, P. Lv, B. Zhang, G.J. Su, L.R. Gao, K. Xiao, A preliminary investigation of unintentional POP emissions from thermal wire reclamation at industrial scrap metal recycling parks in China, Journal of Hazardous Materials 215 (2012) 259-265.

[6] N. Thacker, J. Sheikh, S.M. Tamane, A. Bhanarkar, D. Majumdar, K. Singh, C. Chavhan, J. Trivedi, Emissions of polychlorinated dibenzo-p-dioxins (PCDDs), dibenzofurans (PCDFs), and dioxin-like polychlorinated biphenyls (PCBs) to air from waste incinerators and high thermal processes in India, Environmental Monitoring and Assessment 185 (2013) 425-429.

[7] R. Weber, F. Iino, T. Imagawa, M. Takeuchi, T. Sakurai, M. Sadakata, Formation of PCDF, PCDD, PCB, and PCN in de novo synthesis from PAH: mechanistic aspects and correlation to fluidized bed incinerators, Chemosphere 44 (2001) $1429-1438$.

[8] T. Chen, X.D. Li, J.H. Yan, Y.Q. Jin, Polychlorinated biphenyls emission from a medical waste incinerator in China, Journal of Hazardous Materials 172 (2009) 1339-1343.

[9] G.R. Liu, M.H. Zheng, W.B. Liu, C.Z. Wang, B. Zhang, L.R. Gao, G.J. Su, K. Xiao, P. Lv, Atmospheric emission of PCDD/Fs, PCBs, hexachlorobenzene, and pentachlorobenzene from the coking industry, Environmental Science and Technology 43 (2009) 9196-9201.

[10] G.R. Liu, M.H. Zheng, P. Lv, W.B. Liu, C.Z. Wang, B. Zhang, K. Xiao, Estimation and characterization of polychlorinated naphthalene emission from coking industries, Environmental Science and Technology 44 (2010) 8156-8161.

[11] R. Weber, C. Gaus, M. Tysklind, P. Johnston, M. Forter, H. Hollert, E. Heinisch, I. Holoubek, M. Lloyd-Smith, S. Masunaga, P. Moccarelli, D. Santillo, N. Seike, R. Symons, J.P.M. Torres, M. Verta, G. Varbelow, J. Vijgen, A. Watson, P. Costner, J. Woelz, P. Wycisk, M. Zennegg, Dioxin- and POP-contaminated sitescontemporary and future relevance and challenges, Environmental Science and Pollution Research 15 (2008) 363-393.
[12] T. Takasuga, T. Makino, K. Tsubota, N. Takeda, Formation of dioxins (PCDDs/PCDFs) by dioxin-free fly ash as a catalyst and relation with several chlorine-sources, Chemosphere 40 (2000) 1003-1007.

[13] K. Tuppurainen, A. Asikainen, P. Ruokojarvi, J. Ruuskanen, Perspectives on the formation of polychlorinated dibenzo-p-dioxins and dibenzofurans during municipal solid waste (MSW) incineration and other combustion processes, Accounts of Chemical Research 36 (2003) 652-658.

[14] M. Altarawneh, B. Dlugogorski, E. Kennedy, J. Mackie, Mechanisms for formation, chlorination, dechlorination and destruction of polychlorinated dibenzo-p-dioxins and dibenzofurans (PCDD/Fs), Progress in Energy and Combustion Science 35 (2009) 245-274.

[15] M. Cobo, A. Galvez, J.A. Conesa, C.M. de Correa, Characterization of fly ash from a hazardous waste incinerator in Medellin, Colombia, Journal of Hazardous Materials 168 (2009) 1223-1232

[16] T. Chen, J.H. Yan, S.Y. Lu, X.D. Li, Y.L. Gu, H.F. Dai, M.J. Ni, K.F. Cen, Characteristic of polychlorinated dibenzo-p-dioxins and dibenzofurans in fly ash from incinerators in China, Journal of Hazardous Materials 150 (2008) $510-514$.

[17] T. Ba, M.H. Zheng, B. Zhang, W.B. Liu, K. Xiao, L.F. Zhang, Estimation and characterization of PCDD/Fs and dioxin-like PCBs from secondary copper and aluminum metallurgies in China, Chemosphere 75 (2009) 1173-1178.

[18] T. Ba, M.H. Zheng, B. Zhang, W.B. Liu, G.J. Su, G.R. Liu, K. Xiao, Estimation and congener-specific characterization of polychlorinated naphthalene emissions from secondary nonferrous metallurgical facilities in China, Environmental Science and Technology 44 (2010) 2441-2446.

[19] M. Van den Berg, L. Birnbaum, A.T.C. Bosveld, B. Brunstrom, P. Cook, M. Feeley, J.P. Giesy, A. Hanberg, R. Hasegawa, S.W. Kennedy, T. Kubiak, J.C. Larsen, F.X.R. van Leeuwen, A.K.D. Liem, C. Nolt, R.E. Peterson, L. Poellinger, S. Safe, D. Schrenk, D. Tillitt, M. Tysklind, M. Younes, F. Waern, T. Zacharewski, Toxic equivalency factors (TEFs) for PCBs, PCDDs, PCDFs for humans and wildlife, Environmental Health Perspectives 106 (1998) 775-792.

[20] Y. Noma, T. Yamamoto, S.I. Sakai, Congener-specific composition of polychlorinated naphthalenes, coplanar PCBs, dibenzo-p-dioxins, and dibenzofurans in the halowax series, Environmental Science and Technology 38 (2004) $1675-1680$

[21] A.P.J.M. van Birgelen, Hexachlorobenzene as a possible major contributor to the dioxin activity of human milk, Environmental Health Perspectives 106 (1998) 683-688.

[22] H. Huang, A. Buekens, On the mechanisms of dioxin formation in combustion processes, Chemosphere 31 (1995) 4099-4117.

[23] C. Xhrouet, C. Pirard, E. De Pauw, De novo synthesis of polychlorinated dibenzop-dioxins and dibenzofurans an fly ash from a sintering process, Environmental Science and Technology 35 (2001) 1616-1623.

[24] K. Raghunathan, B.K. Gullett, Role of sulfur in reducing PCDD and PCDF formation, Environmental Science and Technology 30 (1996) 1827-1834.

[25] E. Wikström, S. Ryan, A. Touati, M. Telfer, D. Tabor, B.K. Gullett, Importance of chlorine speciation on de novo formation of polychlorinated dihenzo-p-dioxins and polychlorinated dibenzofurans, Environmental Science and Technology 37 (2003) 1108-1113.

[26] E. Wikström, S. Ryan, A. Touati, B.K. Gullett, Key parameters for de novo formation of polychlorinated dibenzo-p-dioxins and dibenzofurans, Environmental Science and Technology 37 (2003) 1962-1970.

[27] J.E. Oh, B. Gullett, S. Ryan, A. Touati, Mechanistic relationships among PCDDs/Fs, PCNs, PAHs, CIPhs, and CIBzs in municipal waste incineration, Environmental Science and Technology 41 (2007) 4705-4710.

[28] B.K. Gullett, A. Touati, J. Huwe, H. Hakk, PCDD and PCDF emissions from simulated sugarcane field burning, Environmental Science and Technology 40 (2006) 6228-6234.

[29] G.R. Liu, M.H. Zheng, B. Du, Z.Q. Nie, B. Zhang. J.C. Hu, K. Xiao, Identification and characterization of the atmospheric emission of polychlorinated naphthalenes from electric arc furnaces, Environmental Science and Pollution Research 19 (2012) 3645-3650

[30] E. Abad, J. Caixach, J. Rivera, Dioxin like compounds from municipal waste incinerator emissions: assessment of the presence of polychlorinated naphthalenes, Chemosphere 38 (1999) 109-120.

[31] S.N. Meijer, T. Harner, P.A. Helm, C.J. Halsall, A.E. Johnston, K.C. Jones, Polychlorinated naphthalenes in UK soils: time trends, markers of source and equilibrium status, Environmental Science and Technology 35 (2001) 4205-4213.

[32] UNEP, Chemicals, Standardized Toolkit for Identification and Quantification of Dioxin and Furan Releases, UNEP Chemicals, Geneva, Switzerland, 2005, February. 